
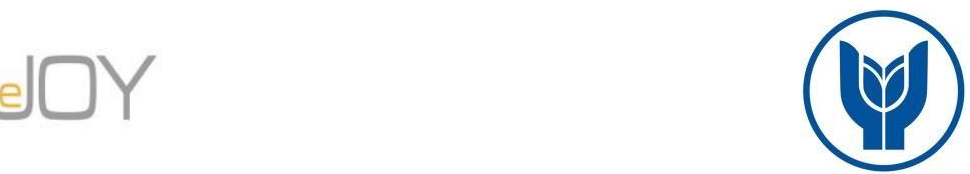

Akgül, V. / Journal of Yasar University, 2020, 15/60, 790-805

\title{
Gönen Termal Turizm Merkezindeki Otel İşletmelerinde Personel Güçlendirme ve Yaratıcılık İlişsisine Yönelik Bir Uygulama ${ }^{1}$
}

\section{An Analysis for Employee Empowerment and Creativity in Hotel Businesses in Gönen Thermal Tourism Center}

\author{
Volkan AKGÜL, Bandırma Onyedi Eylül Üniversitesi, Türkiye, vakgul@bandirma.edu.tr \\ Orcid No: 0000-0002-1248-1425
}

\begin{abstract}
Öz: İşletmelerin, sürdürülebilir rekabet avantajı elde edebilmeleri için önemli etmenlerden biri çalışanlarını desteklenmesidir. Örgütsel yaratıcılı̆̆ın gerçekleşmesi ve sürekliliğinin sağlanabilmesi için çağdaş bir yönetim anlayışı olan personel güçlendirme kavramına önem verilmesi gerekmektedir. Bu sayede emek yoğun bir sektör olan turizmde, insan unsurundan sağlanan fayda artırlabilir. Özellikle termal otel işletmelerinin çalışma alanlarl, çalışma şartlarl ve müşterilerinin diğer otel işletmelerinden farklılaştı̆̆ gözönüne alındĭ̆ında çalışanlara verilecek olan destekler termal otellerde daha da ön plana çıkmaktadır.

Yapılan çalışmanın amacl, personel güçlendirme ve örgütsel yaratıcılık arasındaki ilişkiyi ve demografik değişkenlere göre farklılık durumlarını tespit etmektir. Bunu yaparken; personel güçlendirmenin dört alt boyutu tek tek ele alınarak örgütsel yaratıcılı̆̆ ne yönde etkilediği araştırılmıştır. Araştırılma yapılırken, Balıkesir ili Gönen ilçesindeki termal otel işletmeleri örneklem olarak seçilmiş ve çalışanlardan 151'i anket doldurarak araştırmaya katılmıştır. Ankette personel güçlendirme ile ilgili 12 adet, örgütsel yaratıcılık ile ilgili 21 adet ve demografik bilgilerin bulunduğu sorular sorulmuştur. Likert ölçeği kullanılan anket verileri toplanıp; frekans, korelasyon ve çoklu regresyon analizleri uygulanmıştır. Çalışma sonucunda; personel güçlendirme ve alt boyutlarından anlam, özerklik ve etki boyutlarının örgütsel yaratıcılı üzerinde pozitif yönlü ve anlamlı bir etkiye sahip olduğu tespit edilirken, yetkinlik alt boyutu ile ilgili bir anlamlılık tespit edilememiştir.
\end{abstract}

\section{Anahtar Kelimeler: Personel Güçlendirme, Örgütsel Yaratıcılık, Termal Otel Işsletmeleri}

JEL Sinıflandırması: M50, M54, L84

\begin{abstract}
One of the most important factors enabling companies to achieve sustainable competitive advantage is to support their staff. In order to ensure the realization and continuity of organizational creativity, it is crucial to give importance to the concept of empowerment, which is a modern management approach, in this way, the benefit provided by the human element can be increased in tourism which is a labor-intensive sector. Especially considering the working areas, working conditions and customers of thermal hotel businesses differ from other hotel businesses, the supports to be given to the employees become more prominent in thermal hotels.

The aim of this study is to determine the relationship between empowerment and organizational creativity as well as to determine the differences between demographic variables. How empowerment affects the organizational creativity was investigated by considering four sub-dimensions one by one. In this study, thermal hotels in Ballkesir Gönen district were selected as sample and 151 employees of these hotels participated in the study. The questionnaire included 12 items about staff empowerment and 21 items about organizational creativity and demographic information. The data gathered through Likert scale was examined employing frequency, correlation and multiple regression analyzes. While the findings indicated that staff empowerment and its sub-dimensions, 'meaning', 'autonomy' and 'effect' had a positive and significant impact on organizational creativity; no significant impact was found related to 'competence' sub-dimension.
\end{abstract}

Keywords: Employee Empowerment, Organizational Creativity, Thermal Hotels

JEL Classification: M50, M54, L84

Makale Gecmiși / Article History Başvuru Tarihi / Date of Application : 24 Ocak / January 2020

Kabul Tarihi / Acceptance Date : 29 Mayis / May 2020

(C) 2020 Journal of Yaşar University. Published by Yaşar University. Journal of Yaşar University is an open access journal.

There is no conflict of interest or ethical concern regarding this publication.

${ }^{1}$ Bu çalışma, 20-21 Haziran 2019 tarihlerinde, Bandırma Onyedi Eylül Üniversitesi’nde düzenlenen "II. International Conference on Empirical Economics and Social Sciences" (ICEESS' 19) Konferansı'nda özet bildiri olarak sunulmuştur. 


\section{Giriș}

Sürekli değişen ve gelişen turizm sektöründe işletmeler modern yönetim yaklaşımlarını uygulayarak rakiplerinin önüne geçmek zorundadırlar. Personel güçlendirme, bu yaklaşımların en önemlilerinden biridir. Personel güçlendirme kavramı yetki ve sorumlulukların çalışanlara devredilerek, onların işlerini yapmalarında özgür ve bağımsız olacakları bir yönetim anlayışının yaratılmasına olanak verir bu sayede çalışanların daha yaratıcı ve yenilikçi yönlerini ortaya çıkarmalarına vesile olur. Bu sayede çalışanların işletmelerindeki verimlilikleri yükselirken aynı zamanda müşteri memnuniyeti arttırılmış olur.

Yaratıcılık, bir birey tarafından veya birlikte çalışan bir grup insan tarafından yeni ve faydalı fikirlerin üretilmesi anlamına gelir (Sun, v.d. 2012;55). Çalışanlar, örgüt içinde yönetim tarafından oluşturulan destekleyici ve pozitif bir ortam hissederlerse kişisel gelişimlerine daha fazla eğilim gösterebilmektedirler. Çalışanların yaratıcılıklarını ortaya çıkarması, geliştirmesi ve kullanabilmesi, bulunduğu işletmenin yapısıyla doğru orantılıdır. Yaratıcılık; işletmelerin yeni ürün ve hizmetler geliştirmelerini, mevcut ürün ve hizmetleri değişen koşullara uygun hale getirmelerini, pazar paylarını artırırken aynı zamanda rakiplerinden farklı olmalarını sağlamaktadır. İşletmeleri başarıya ulaştırmanın yolu yaratıcı ve yenilikçi olmaktan geçmektedir (Samen, 2008: 376). Bu sebeple işini sahiplenen, kendi işiyle alakalı karar alabilme özgürlüğüne sahip olan, yaratıcılığın ve yenilikçiliğin ilk sırada olduğu bir yaklaşım olan "personel güçlendirme" işletmelerin ihtiyaç duyduğu bir önemli bir yönetim stratejisidir (Tetik, 2015: 408).

Emek yoğun bir sektör olan turizmde, otel işletmelerinin sundukları hizmetlerde etkili ve verimli olabilmeleri, bu işletmelerde bulunan çalışanların göstermiş oldukları katkılarla sağlanmaktadır. $\mathrm{Bu}$ nedenle, çalışanların iş hayatlarında yaşadıkları psikolojik etkenlerin, onların yaptıkları işe karşı tutumlarında, müşterilerle ve diğer personelle olan iletişimlerinde önemli olduğu görülmektedir. Turizm sektörü; insan kaynağı devir hızının en hızlı yaşandığı ve kalifiye personel sıkıntısının yoğun hissedildiği alanlardan biridir. Artan rekabet içerisinde, hizmet üretmeye ve müşteri memnuniyeti sağlamaya çalışan bu işletmeler arasındaki belirleyici fark; çalıştırdığı personel olmaktadır.

Termal otel işletmeleri çalışanlarının, görev yaptıkları fiziki alan ve çalışma şartları diğer turizm sektör çalışanlarınkinden farklılık gösterebilmektedir. Mekan 1sıları yüksek olan ve temizlik, hijyen gibi sebeplerle özel kimyasalların ve temizlik malzemelerinin kullanıldığı; Türk hamamı, fizik tedavi üniteleri, sauna, sıcak su havuzları gibi yerler, görev yapması zor olabilen çalışma alanlarıdır. Termal otel işletmeleri, müşterileri bakımında da diğer otel işletmelerinden farklılık göstermektedir. Otele gelen konuklar içerisinde gezme, görme, 
eğlenme, dinlenme vb. amaçlarla gelen olduğu gibi sağlık, şifa arayan hastalar da olabilmektedir. Yapılan işin insan sağlığı odaklı olması, termal otel işletmeleri ve bağlı birimlerinde gerçekleştirilen işlerin teknik bilgi ve uzmanlığa dayalı olması sonucunu doğurmaktadır. Bilgi ve uzmanlığa dayalı işlerde sorumluluk derecelerinin de yüksek olduğu bir gerçektir. Bu sebeple müşterilerine karşı daha özenli ve dikkatli hizmet verme gerekliliğini ortaya çıkmaktadır. Belirtilen özellikleri nedeniyle termal otel işletmelerinde, personel güçlendirme oldukça önemli bir kavram olarak ele alınmalıdır. Bu aşamada, insan kaynakları yönetim teknikleri açısından personel güçlendirme ön plana çıkmaktadır. Söz konusu tesisler diğer bütün konaklama işletmelerinde olduğu gibi, personeline yaptığı güçlendirme faaliyetleri sonrasında onların yaratıcılıklarının gelişmesine katkı sağladıklarında müşteri memnuniyetini arttırırken aynı zamanda rekabet avantajı sağlayacaklardır.

Termal otel işletmesi yöneticileri, çalışanlarını izlemeli, eksik yönleriyle ilgili onları uyarmalı ve takım çalışması içerisinde görev yapmalarını sağlamalıdırlar. Turizm sezonunun düştüğü dönemlerde çalışanları motive edecek ve kaynaştıracak etkinlikler düzenlenmeli ve özellikle termal işletmelerde, başta fizik tedavi ve banyo bölümlerinde çalışan personele yönelik, temizlik ve hijyen ve iş güvenliği olmak üzere teknik konularında hizmet içi eğitimler verilmeli ve kullanılan kimyasallar ve etkileri konusunda çalışanlar bilinçlendirilmelidir.

Literatürde çalışma ortamının özellikleri farklılık gösterse de, termal turizm ve konaklama organizasyonlarını inceleyerek hizmet sektöründe personel güçlendirme ve örgütsel yaratıcılık arasındaki ilişkiyi inceleyen az sayıda araştırma yapılmıştır. Bu bağlamda, Spreitzer (1995), tarafından geliştirilen ve personel güçlendirmenin 4 boyutu (Anlam, Yeterlilik, Özerklik ve Etki) ile örgütsel yaratıcılık arasındaki ilişkiler incelenmiştir. Yapılan çalışmanın, termal otel işletmeleri, örgüt psikolojisi, güçlendirme ve yaratıcılık ile ilgili ileride yapılacak çalışmalara katkıda bulunacağı düşünülmektedir.

\section{Literatür Taraması}

\subsection{Personel Güçlendirme}

Personel güçlendirme kavramının tarihi incelendiğinde birçok farklı betimleme karşımıza çıkmaktadır. Personel güçlendirmeyi bir güdüleme faktörü olarak tanımlayan yazarlar olduğu gibi (Kabak, 2014:10); çalışanların paylaşma ve dayanışma ile ekip çalışmasına katkıda bulundukları ve bu sayede yönetim kararlarına katılımlarının sağlandığı bir süreç olarak da tanıma katkıda bulunanlar olmuştur (Koçel, 2014:470). Brymer'a göre ise personel güçlendirme; örgütteki karar verme sürecinin tek merkezden uzaklaştırılması anlamını taşımaktadır (Brymer, 1991:59). 
1990'lı yıllardan sonra önemi daha çok anlaşılan personel güçlendirme kavramının popülerliği günümüzde daha da artmaktadır. Farklı ifade ediş biçimlerine rağmen güçlendirmede altı çizilen en önemli şey, kişinin kendi etkinliği hakkında inancının güçlendirilmesi davranışının örgütlere kazandırılması olmuştur (Conger, 1989:17). Güçlendirmenin kökü "güven” duygusuna dayanmaktadır. Çalışanların iş yapma şekillerine, bilgilerine, yeteneklerine, kurumsal yapı ve kültürüne güvenmesi gerekmektedir (Toktamışoğlu, 2002: 212). Örgüt tarafından daha güçlü kılınan insan kaynağı, kendine çok daha fazla güvenecek ve kendisi, parçası olduğu işletme ve bulunduğu toplum için daha iyi şeyler yapmış olacaktır. Güçlendirilen çalışan örgüt içinde daha aktif olacağı için daha verimli olacak ve örgütün başarısını katlamasını sağlayacaktır (Pelit, Öztürk ve Arslantürk, 2011:387).

Günümüz şartlarında, hizmet kalitesini yükseltmek ve müşteri istek ve ihtiyaçlarını karşılayabilmek için işletmeler; yapılarını ve örgüt kültürlerini geliştirmek amacıyla personel güçlendirme çalışmalarına öncelik vermek zorundadırlar. Personel güçlendirme, personel yetki ve yetkinliklerini geliştirmekle çevreden gelen tepkimelere işletmelerin cevap verme hızını arttırmaktadır.

Personel güçlendirme ile mükemmel müşteri hizmeti sunulabilecek ve müşteri isteklerine hızla cevap verilecektir (Frogoso, 2000, s.3). Özellikle hizmet sektöründe yer alan işletmeler açısından söz konusu olabilecek bu artı değer ile, gerekli yeteneğe ve yeterliliğe sahip, inisiyatif kullanma yetkisi ile donatılmış güçlendirilmiş personel, müşterinin ihtiyaç ve isteklerine daha hızlı cevap verebilecektir. Termal otel işletmelerinde özellikle fizik tedavi ünitelerinde çalışan personelin uymakla yükümlü olduğu kuralar dışında, alacağı kararlar ve yapacağı hareketler, sağlık sebebiyle gelmiş olan müşterilerin tatmini artırarak müşteri memnuniyetlerini sağlayacak ayrıca otele yeniden gelmelerini ve bu işletmeyi tavsiye etmelerini kolaylaştıracaktır.

Spreitzer (1995), personel güçlendirmenin psikolojik boyutuna odaklanmakta ve bunu da dört boyutta değerlendirmektedir. Bunlar; anlam, yeterlilik, özerklik ve etki'dir. Spreitzer (1995), bu dört boyutlu modeli oluştururken Thomas ve Velthouse (1990: 670)'un model fikrini desteklemiş sadece "seçim" boyutunu "özerklik" olarak isimlendirmiş ve bu boyutlardan her birinin psikolojik güçlendirmeyi genel olarak ölçmek için bir bütün olarak ele alınması gerektiğini belirtmiştir.

Anlam: Çalışanların işleri ile değerleri, inançları ve fikirleri arasındaki tutarlılığı ifade etmektedir (Spreitzer, 1996: 484). Çalışanın yaptığı işin kendisi için anlam ifade etmesi işletmeye olan bağlılığının, katkısının ve işine karşı gösterdiği önemin artmasına olanak 
sağlamaktadır. Aynı şekilde, yapılan işin çalışana herhangi bir anlam ifade etmemesi örgüte olan bağlılığının azalmasına, işine karşı gerekli özeni göstermemesine ve ilgisiz bir tavır takınmasına yol açmaktadır (Çavuş ve Demir, 2011: 217).

Yeterlilik: Çalışanların yaptıkları işin gereklerini yerine getirecek bilgi ve beceriye sahip olmasını ifade etmektedir (Spreitzer, 1996: 484). "Kişinin işini en iyi şekilde yapabileceği yönünde kendi yeteneklerine olan inancıdır. Diğer bir ifadeyle, bireyin işini ve iş ortamını şekillendirmek istemesi ve bunu yapacak yeterliliğe sahip olmasıdır" (Ceylan vd., 2005: 37).

Özerklik: Çalışanın kendi başına karar verebileceği, görev ile ilgili geleceğini belirleyebileceği ve özgür bir şekilde davranabileceği durumları ifade etmektedir (Spreitzer, 1996: 484). Bireyin seçim yapması yaratıcılığa, esnekliğe, inisiyatif kullanmaya ve rahatlığa imkan tanıyacak; duygusal sıkıntı yaşanmayacak ve öz-saygı kaybolmayacaktır (Thomas ve Velthouse, 1990: 673).

Etki: Çalışanın görevleri ile ilgili operasyonel, stratejik ve yürütme çıktılarını etkileme düzeyini ifade etmektedir (Spreitzer, 1996: 484). Çalışanın görev ve sorumluluğu altındaki işin çıktılarını etkileyebilmesi, güçlendirilmiş hissi yaratmaktadır (Çavuş ve Demir, 2011: 218). Yine başka bir ifade ile etki; işi alakadar eden çıktıları kimin kontrol ettiğine ilişkin kişinin yapmış olduğu kontrollerdir (Bolat, 2003: 205).

$\mathrm{Bu}$ dört boyut yukarıda belirtildiği şekilde kapsamlı olarak birleştirildiğinde, psikolojik güçlendirme ile alakalı bütüncül bir kavram belirmektedir. Eğer boyutlardan bir tanesi dahi eksilirse güçlendirme duygusunun derecesi düşmektedir. Bundan dolayı, tanımlanan dört boyut beraberce psikolojik güçlendirmeyi anlamak için gereken "tam ve bilişsel bir set" olarak da ifade edilmektedir (Hu ve Leung, 2003).

\section{2. Örgütsel Yaratıcılık}

Yaratıcılık ve düşünme bireysel olmakla beraber güven ve işbirliği duyulan bir takım durumlarda daha çok gelişir. Yaratıcılık ne düzeyde olursa olsun daima bireyseldir. Kurumlar dayanışma ortamı ve işbirliği oluşturarak, ortak hedefler doğrultusunda belirli sistemler aracılığıyla çalışanların yeteneğini geliştirir, açığa çıkmasını sağlar ve kullanırlar (Simonton, 2000: 285).

İşletmeler arasında rekabet etmenin ve ayakta kalmanın yollarından biride örgütsel yaratıcılık kavramıdır. Kendir ve Özkoç (2019), Afyonkarahisar'da 3, 4 ve 5 yıldızlı otel işletmelerinde çalışan 374 personelin, örgütsel yaratıcılık boyutlarını algılama düzeylerini saptamaya çalıştıkları çalışmada; sağlık turizmi ve termal turizm alanlarında faaliyetlerini sürdüren otellerin yaratıcılık kavramını örgütün tamamına yaymalarının gerekli olduğu ve bu alanda faaliyet gösteren işletmeler arasında rekabet etmede yaratıcılığın önemini 
belirtmişlerdir. Watt (2007), yaratıcılığı; “örgüt içindeki bireylerin ve çalışma ortamının yaratıcı çıktılarının bir işlevi” olarak nitelemiştir. Genel anlamda yaratıcılık, yaratıcı birey tarafından gerçekleştirilen bir faaliyet olduğundan, örgütlerin yaratıcı olmalarını sağlayacak yine çalışanlarıdır. $\mathrm{Bu}$ sebeple, örgütlerde insan kaynağı üzerine önemle durulmalı, çalışanların yaratıcılıklarını geliştirmelerine ve kullanmalarına imkan sağlayacak iş ortamının oluşturulması gerekmektedir (Eren ve Gündüz, 2002: 82). Sezgin, v.d. (2008), Konya'daki 3, 4 ve 5 yıldızlı otel işletmelerinin, üst düzey yöneticileri ve yiyecek içecek departmanı yöneticilerine yönelik yaptıkları araştırmada; menü planlamasında yaratıcılık ve yenilikçiliğin önemini belirterek otel işletmelerinde görev alan çalışanlara verilecek eğitimlerde yaratıcılık ve yenilik kavramlarının önemini vurgulamışlardır.

Uğurlu ve Ceylan, (2014)'e göre; yöneticilerin yaratıcılığı destekleyici davranışları örgütsel yaratıcılığın oluşturulmasında önemli bir etkendir. Yaratıcı örgüt kültürü oluşturmak için yöneticilerin yönetim şeklinde dikkat etmesi gereken davranış biçimleri bulunmaktadır. Bu davranış biçimleri:

- Alt kademede çalışan personellere danışman gibi davranarak yaratıcı yeteneğe sahip personelin özelliklerini ortaya çıkarma konusunda yardımcı olmalı,

- Çalışanlara yaptıkları işler konusunda otonomi ve özgürlük imkânı sağlanması,

- Yaratıcı çabaları destekleme ve teşvik amacıyla ödüllendirme sistemi uygulanması,

- Örgüt içinde iletişim ve bilgi paylaşımına önem verilmesi,

- Yaratıcılık çalışmalarını destekleme amaçlı kaynak sağlanması, olarak ifade edilmektedir.

Günümüz yöneticileri, yönettikleri işletmelerde sürdürülebilir başarıyı sağlayabilmek için işletme içindeki yaratıcılık duygusundan haberdar olmalı, yaratıcılığı gözlemlemek ve işletmelerinde bu amaçlara uygun değişiklikleri yapmaları gerekmektedir (Önal, 1979, s.61). Akgündüz (2013), Kuşadası'nda 5 yıldızlı otel işletmelerinde görev yapan 184 çalışana yönelik yaptığı araştırmada; yöneticilerin, çalışanların yaratıcılığını artırmak için dışsal motivasyon araçlarına göre içsel motivasyon araçlarına daha fazla önem vermesi gerektiğini belirtmiştir.

\subsection{Personel Güçlendirme ve Örgütsel Yaratıcılı Arasındaki İlişki}

Personel güçlendirme ile örgüt kültürünün yaratmış olduğu bu pozitif hava çalışanların uyumluluğunu, güvenilirliğini ve yardımseverliğini artırmaktadır. Aynı zamanda çalışanların teşvik edilmesine imkân sağlayan destekleyici iş ortamı onların yaratıcılık özelliklerinin çoğalmasını sağlamaktadır. 
Örgüt bünyesindeki bu bireylerin yaratıcılığının ortaya çıkmasını sağlamak için ise yönetimin gerekli kaynakları sağlaması, bireylerin ihtiyaçlarını gidermesi, çalışanları desteklemesi gerekmektedir. Nihayetinde bu çalışanların ilgi düzeyinin artmasına da bağlıdır (Oldham ve Cummings, 1996: 611).

Çalışanların yaratıcı davranışı, örgüt hedeflerine ulaşabilmek için mevcut iş düzeninde ya da işin gerçekleşmesiyle alakalı sorunlara özgün ve daha uygun yöntemler geliştirmeyi kapsayan davranışlardır. Yaratıcılık, dinamik ve toleransın aktif olduğu ortamlarda gelişim gösterir. Yaratıcı çalışanlar rutinden hoşlanmaz, verilmiş olan görevleri nasıl becerebileceklerine ilişkin fikirlere sahip olan bireyler olarak destekleyici yönetim tarzına ihtiyaç duyarlar. İlk olarak yaratıcılı̆̆ı geliştirmede yöneticilerin yaratıcı süreci kavrayabilmeleri, yaratıcı davranışa özendirmeleri ve yaratıcılığın gelişimini gerçekleştirebileceği örgüt ortamı kurmaları gerekmektedir. Kurumsal motivasyon ve teşvik çalışanların yaratıcılık düzeyini artırır (Rice, 2006: 233-241).

Ghorbani ve Ahmadi (2011), eğitim kurumlarında yaratıcılığın geliştirilmesi ve personel güçlendirmenin boyutları arasındaki ilişkiyi ele aldığı araştırmalarında, anlam, yetkinlik, otonomi ve etki boyutlarının tamamımın personel güçlendirme ile pozitif yönde ilişkiye sahip olduğunu tespit etmiştir. Araştırmacılar eğitim kurumlarında yönetici olarak görev yapan kişilerin, insan kaynağının yaratıcılığını olumsuz etkileyen unsurları ortadan kaldırması gerektiğini vurgulamıştır.

Sun, v.d. (2012), Çin Halk Cumhuriyeti'nin Guangdong eyaletinde bulunan birden fazla ilaç firmasında; 385 çalışan ve onların 104 amirleriyle yaptıkları çalışmada iş ortamlarında güçlendirme uygulamalarının ve özerk bir çalışma ortamını geliştirmelerinin astların yaratıcılıklarını arttırdığını belirmişlerdir.

Choi ve Chang (2014), psikolojik sermaye, personel güçlendirme ve yaratıcılık arasındaki ilişkiye motivasyonun aracı etkisini ele alan bir çalışma yürütmüştür. Personel güçlendirmenin ise yaratıcılık üzerinde doğrudan etkisinin önemsiz olduğunu vurgulamıştır.

Uzunbacak (2015), Isparta ve Burdur Organize Sanayi Bölgeleri'nde çalışanların katılımıyla yürüttüğü araştırmada, personel güçlendirmenin yaratıcılık üzerine etkisini incelemiştir. Araştırma bulguları güçlendirme ile ilgili tüm unsurların yaratıcılık üzerine pozitif yönde etki edebileceğini ortaya koymuştur.

Tsai ve dĭ̆. (2015), Turizm sektöründe çalışan 320 kişi ile yaptıkları çalışmalarında; örgütsel desteğin, örgütsel çalışma ortamını ve yaratıcılığı kolaylaştıran atmosferi nasıl etkilediğine dair yeni bir model test etmişler ve örgütsel destek ve çalışanların yaratıcılığ arasında çalışma ortamının aracılık rolünün olduğunu belirtmişlerdir. 
K1lıç (2018), Konya ilinde süt endüstrisinde faaliyet gösteren işletmelerde çalışan 370 kişi ile yaptığı çalışmada personel güçlendirmenin alt boyutları olan anlam, yetkinlik, özerklik ve etki boyutlarının örgütsel yaratıcılık üzerinde pozitif yönlü ve anlamlı bir etkiye sahip olduğu tespit edilmiştir.

Haykır (2018), Antalya'da faaliyet gösteren beş yıldızlı otel işletmelerinin mutfak bölümünde çalışan aş̧̧ılara yönelik bir araştırma gerçekleştirilmiştir. Elde edilen sonuçlara göre insan kaynakları yönetimi yaklaşımlarından olan personel güçlendirme ile yaratıcılık arasında pozitif anlamda bir ilişki bulunmaktadır.

Bu bilgiler doğrultusunda araştırmanın hipotezleri aşağıdaki gibi belirlenmiştir

H: Termal otel işletmelerinde personel güçlendirme, örgütsel yaratıcılığı pozitif yönde etkiler.

$\mathrm{H}_{1}$ : Personel Güçlendirmenin Anlam alt boyutu, Örgütsel Yaratıcılığı pozitif yönde etkiler.

$\mathrm{H}_{2}$ : Personel Güçlendirmenin Yeterlilik alt boyutu, Örgütsel Yaratıcılığı pozitif yönde etkiler.

$\mathrm{H}_{3}$ : Personel Güçlendirmenin Özerklik alt boyutu, Örgütsel Yaratıcılığı pozitif yönde etkiler.

$\mathrm{H}_{4}$ : Personel Güçlendirmenin Etki alt boyutu, Örgütsel Yaratıcılığı pozitif yönde etkiler.

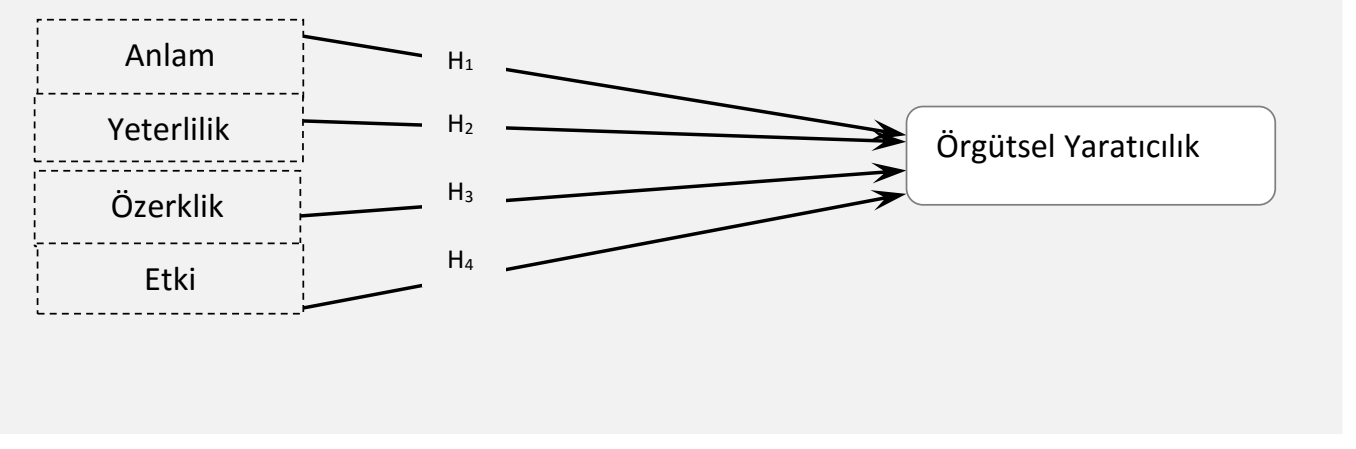

Şekil 1. Araştırmanın modeli

\section{Yöntem}

\subsection{Araştırmanın Amacı}

Personel güçlendirme kavramı sayesinde işletmelerde yetki ve sorumluluklar çalışanlara devredilerek onların işlerini yapmalarında özgür ve bağımsız olacakları bir yönetim anlayışı yaratılmaktadır. Bu sayede çalışanların daha yaratıcı ve yenilikçi yönlerini ortaya çıkarmaları kolaylaşır ve çalışanların işletmedeki verimliliklerini artar.

Yapılan çalışmanın amacı, personel güçlendirme ve örgütsel yaratıcılık arasındaki ilişkiyi ve demografik değişkenlere göre farklılık durumlarını tespit etmektir. Bunu yaparken; personel güçlendirmenin dört alt boyutu (Anlam, Yeterlilik, Özerklik, Etki) tek tek ele alınarak örgütsel yaratıcılığı ne yönde etkilediği araştırılmıştır. 


\subsection{Veri Toplama Araçlart}

Araştırmada veri toplama yöntemi olarak anket tekniği kullanılmıştır. Oluşturulan anket formunun birinci bölümünde, personel güçlendirme ölçeği olarak Spreitzer (1995) tarafından geliştirilen ölçek kullanılmıştır. Özdemir (2017)'den alınan ölçek, farklı zamanlarda ve alanlarda araştırmacılar tarafindan kullanıldığından, ölçeğin yapı geçerliliği bu çalışmalar ile ispat edilmiştir (Kraimer vd., 1999, s.138; s.874, Ergeneli vd., 2007, s.44). Spreitzer (1995) personel güçlendirmeyi, 4 boyutta (Anlam, Yeterlilik, Özerklik ve Etki) 12 adet Likert tipi (5'li) ifade ile değerlendirmektedir. Anlam (Meaning) boyutu: Yapılan iş ile çalışanın inanç, değer ve yargıları arasındaki uyumu ifade eder. Yeterlilik (Competence) boyutu: Çalışanın yaptığı işin gereklerini yerine getirecek yetenek ve inanca sahip olduğunu ifade eder. Özerklik (Self-determination) boyutu: Kendi kararını verebilme, bireyin kendi geleceğini belirlemesi ve özgürce hareket edebilmesidir. Kişinin işi üzerindeki kontrol gücü olarak değerlendirilebilir. Etki (Impact) boyutu: kişinin işiyle ilgili operasyonel, stratejik ve yönetsel çıktıları etkileme derecesidir. Bu boyutların her biri için üçer soru sorulmaktadır. Örgütsel yaratıcılığı ölçmeye yönelik ifadeler ise Çavuş (2006)'dan alınmıştır. Ölçekte toplam 21 adet Likert tipi (5'li) ifade yer almaktadır. Anket formunun ikinci bölümünde çalışanların demografik özelliklerini tespit etmeye yönelik toplam 8 soru (cinsiyet, medeni durum, çalıştı̆̆ınız departman ve göreviniz, yaş, eğitim, sektör tecrübesi ve kişisel aylık gelir) yer almaktadır.

\section{3. Örneklem}

Araştırmanın evrenini, Balıkesir ili, Gönen ilçesinde faaliyet gösteren termal otel işletmelerinin çalışanları oluşturmaktadır. Mart 2019 tarihi itibari ile Gönen Belediye Başkanlığ̣ web sayfasından yapılan inceleme sonucu; Gönen Kaplıcaları bünyesinde Kültür ve Turizm Bakanlığı İşletme Belgeli (4 yıldızlı) 1 otel ve hemen yanında Belediye tarifeli 4 konaklama tesisi bulunmaktadır. Tesisler ile yapılan görüşmeler sonucu tesislerde toplamda 290 personel çalıştı̆ğ tespit edilmiştir. Ana kütleden \%95 güvenilirlik sınırları içerisinde \%5'lik bir hata payı dikkate alınarak örneklem büyüklügü 165 kişi olarak hesap edilmiştir (Sekaran, 2003; Yazıcığlu ve Erdoğan, 2004).

Oluşturulan anket formu 15 Mart -15 Nisan 2019 tarihleri arasında ilçede faaliyet gösteren tesislerde çalışanlara yüz yüze uygulanmış ve 169 adet anket toplanmıştır. Yapılan incelemede 18 adet ankette, analiz açısından sorun oluşturabilecek düzeyde boş ve hatalı kodlama olduğu tespit edilmiştir. Bu 18 anket örneklemden çıkarılmış ve kalan 151 örneklem ile analize geçilmiştir. Araştırmanın sektörel olarak genelleme amacı bulunmamaktadır. 
Demografik değişkenlere ait analizler incelendiğinde, ankete katılan otel çalışanların bayan-erkek dağılımının birbirine yakın olduğu (Kadın \%44,4- Erkek \%55,6) ve ağırlıklı olarak ortaöğretim $(31,5)$ ve ön lisans $(31,8)$ mezunu oldukları görülmektedir. Yaş gurupları bakımından en yüksek oran; $(\% 31,8)$ ile $41-50$ ve $(28,25)$ ile $31-40$ yaş aralığındadır. Sektör tecrübeleri incelendiğinde ise en yüksek oranın $(\% 27,8)$ ile 6-10 yıl ve onu takip eden oranın $(\% 26,5)$ ile 2-5 y1l olduğu ve nispeten işletmelerde çalışan personelin tecrübeli olduğu düşünülebilir. Aylık ortalama gelir açısından \%66,2 ile 2001-3000 TL aralığı görülmektedir.

\section{Bulgular}

Araştırma yöntemi ile elde edilen verilere öncelikli olarak katılımcıların demografik özelliklerini tespit etmek amacıyla frekans analizi uygulanmıştır. Daha sonra araştırmada kullanılan; Personel Güçlendirme ve Örgütsel Yaratıcılık ölçeklerinin güvenirliliği için Cronbach's Alpha katsayısı incelenmiştir. Araştırmada kullanılan değişkenlerin çarpıklık ve basıklık ölçebilmek için Skewness-Kurtosis (+1.5 ile -1.5) testleri yapılmıştır, Tablo 1 'de değerler verilmektedir. Modeldeki değişkenlerin test edilebilmesi amacıyla tanımlayıcı istatistikler, korelasyon analizi, çoklu regresyon analizi uygulanmıştır.

Tablo 1. Basıklık Çarpıklık Değerleri

\begin{tabular}{l|l|l}
\hline Değişken & Basıklık (Kurtosis) & Çarpıklık (Skewness) \\
\hline Personel Güçlendirme &,- 162 &,- 812 \\
\hline Örgütsel Yaratıcılık &, 438 &,- 327 \\
\hline
\end{tabular}

Değişkenler incelendiğinde, tüm değişkenlere ait basıklık ve çarpıklık değerlerinin $-1,5-+1,5$ arasında olduğu görülmüştür. Bu nedenle verilerin normal dağıldığı kabul edilebilmektedir (Tabschnich \& Fidell, 2007). Bu nedenle ilgili hipotezlerin test edilmesinde parametrik analiz tekniklerinden yararlanılmasına karar verilmiştir.

\subsection{Güvenilirlik Analizi}

Araştırma kapsamında yapılan güvenilirlik analizi neticesinde Cronbach's Alpha katsayıları incelenmiştir. $\mathrm{Bu}$ değerin en az 0,60 olması gerekmektedir (Gürbüz ve Şahin, 2017). Kullanılan ölçeklerin ve alt boyutlarının katsayıları incelendiğinde, güvenilirlik seviyelerinin iyi olduğu belirlenmiştir. Tüm ölçeklere ait güvenilirlik analizi sonuçları Tablo 2'de sunulmaktadir.

Tablo 2. Güvenilirlik Analizleri

\begin{tabular}{l|c|c}
\hline Ölçek & İfade Sayıs & Cronbach's Alpha \\
\hline Personel Güçlendirme & 12 &, 78 \\
\hline (Anlam) & $(3)$ &, 81 \\
\hline (Yeterlilik) & $(3)$ &, 68 \\
\hline (Özerklik) & $(3)$ &, 73 \\
\hline
\end{tabular}




\begin{tabular}{l|c|c}
\hline (Etki) & $(3)$ &, 76 \\
\hline Örgütsel Yaratıcılık & 21 &, 85 \\
\hline Tüm Ölçek & 33 &, 89 \\
\hline
\end{tabular}

\subsection{Korelasyon ve Regresyon Analizi Sonuçlart}

Personel Güçlendirme alt boyutları ile Örgütsel Yaratıcılık arasındaki ilişkiyi test etmeye yönelik yapılan korelasyon analizi sonucu elde edilen Pearson Korelasyon Katsayısı değerleri aşağıda Tablo 3'de gösterilmiştir. Kesin sınırlamalar olmamakla birlikte 0,50'nin altında korelasyon zayıf, 0,50 ile 0,70 arasında korelasyon orta, 0,70 üzeri korelasyonda kuvvetli ilişkiden bahsedilebilir (Durmuş vd., 2013: 145). Tabloya göre bağımlı ve bağımsız değişkenlerin birbirleri arasında pozitif ilişkilerin olduğu söylenebilir.

Tablo 3. Değişkenler Arasındaki Korelasyonlar

\begin{tabular}{|c|c|c|c|c|c|c|c|}
\hline Değişkenler & Ort. & S.S. & 1 & 2 & 3 & 4 & 5 \\
\hline \multirow[t]{2}{*}{ 1.Anlam } & & ,27 & & & & & \\
\hline & 4.01 & 2 & 1 & & & & \\
\hline \multirow[t]{2}{*}{ 2.Yeterlilik } & &, 06 &, $504^{*}$ & \multirow[b]{2}{*}{1} & & & \\
\hline & 3,48 & 1 & * & & & & \\
\hline \multirow[t]{2}{*}{ 3.Özerklik } & & ,06 &, $306^{*}$ & ,413* & \multirow[b]{2}{*}{1} & & \\
\hline & 3,98 & 7 & * & $*$ & & & \\
\hline \multirow[t]{2}{*}{ 4. Etki } & & ,05 &, $315^{*}$ & & & \multirow[b]{2}{*}{1} & \\
\hline & 3,75 & 6 & * &, $422^{* *}$ &, $310^{* *}$ & & \\
\hline \multirow[t]{2}{*}{ 5. Yaratıcılık } & &, 05 & ,546* & & & & \\
\hline & 3,92 & 7 & * &, $405^{* *}$ &, $543^{* *}$ &, $552^{* *}$ & 1 \\
\hline
\end{tabular}

${ }^{*} \mathrm{p}<0,05$ (Çift Yönlü); **p<0,01 (Çift Yönlü)

Korelasyon analizi sonucu ilişkiler tespit edildikten sonra hipotezleri test etmeye yönelik çoklu doğrusal regresyon analizi yapılmıştır. Sonuçlar Tablo 5’ da gösterilmektedir.

Tablo 4. Model Özeti

\begin{tabular}{|c|c|c|c|c|c|c|}
\hline $\mathbf{R}$ & $\mathbf{R 2}$ & 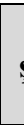 & $\begin{array}{l}\text { Düzeltilmi } \\
\text { R2 }\end{array}$ & $\begin{array}{l}\text { Durbin } \\
\text { Watson }\end{array}$ & $\begin{array}{c}\text { ANOVA F } \\
\text { değeri }\end{array}$ & $\begin{array}{r}\text { Anova } \\
\text { Anlamlılık }\end{array}$ \\
\hline, $675^{\mathrm{a}}$ & , 455 & &, 444 & 1,542 & 40,954 &, $000^{\mathrm{b}}$ \\
\hline
\end{tabular}

Yapilan analizler sonucu Oto korelasyon problemi yoktur (D.W=1,542). Model genel olarak anlamlıdır (Anova $\mathrm{p}=0,000$ )

Tablo 5. Regresyon Analizi Sonuçları

\begin{tabular}{c|c|c|c|c|c|c|c}
\hline \multicolumn{1}{c|}{ Bağımlı Değişken: Örgütsel Yaratıcılık } & \multicolumn{1}{|c|}{} & \\
Bağımsız Değişkenler & $\mathbf{B}$ & $\begin{array}{c}\text { Standart } \\
\text { Hata }\end{array}$ & Beta & $\begin{array}{c}\mathbf{t} \\
\text { değeri }\end{array}$ & p değeri & $\begin{array}{c}\text { VIF } \\
\text { Değeri }\end{array}$ & Sonuç \\
\hline Sabit &, 914 &, 272 & & 3,358 &, 001 & & \\
\hline Anlam &, 346 &, 061 &, 406 & 5,710 &, 000 & 1,361 & H1 desteklendi \\
\hline
\end{tabular}




\begin{tabular}{c|c|c|c|c|c|c|c}
\hline Yeterlilik &, 030 &, 067 &, 033 &, 446 &, 656 & 1,487 & H2 desteklenmedi \\
\hline Özerklik &, 334 &, 056 &, 405 & 6,017 &, 000 & 1,225 & H3 desteklendi \\
\hline Etki &, 322 &, 057 &, 402 & 6,010 &, 000 & 1,234 & H4 desteklendi \\
\hline
\end{tabular}

$(0,914+0,346 \mathrm{G} 1+0,030 \mathrm{Gi}+0,334 \mathrm{G} 3+0,341 \mathrm{G} 4+\mathrm{E})$

Regresyon analizi, bağımsız değişkenler arasında çoklu bağlantı varsa doğru sonuç vermemektedir. Korelasyon analizi sonucu Anlam, Yeterlilik, Özerklik ve Etki alt boyutları arasında $r>7$ olduğu için çoklu bağlantı olma riskine karşı değişik kriterler incelenmiştir. Durbin Watson değeri incelenmiş ve Oto korelasyon problemi olmadiğı görülmüştür (D.W=1,542). Model genel olarak anlamlıdır (Anova $\mathrm{p}=0,000$ ). Daha sonra Varyans Büyütme Faktörü (VIF) değerlerine bakılarak en yüksek değerin 1,487 olduğu ve bu değerin 10 değerinden küçük olması dolayısıyla çoklu doğrusallık problemin olmadığı görülmüştür.

Regresyon yorumunda: Anlam, Özerklik ve Etki alt boyutların etkisi anlaml, Yeterlilik boyutunun ki ise anlamsızdır. Buna göre Anlam alt boyutunda meydana gelen 1 birimlik artış, yaratıcılığı 0,346 birim arttırmaktadır. Aynı şekilde özerklik alt boyutunda meydana gelen 1 birimlik artış, yaratıcığı 0,334 birim arttırmaktadır. Etki alt boyutunda meydana gelen 1 birimlik artış yaratıcığı 0,322 birim arttırmaktadır. Yaratıcılığın varyansındaki değişimin \%45,5 lik bir kısmı, modele dahil olan değişkenler tarafından açıklanmaktadır.

\section{Tartışma ve Sonuç}

İşletmelerin, sürdürülebilir rekabet avantajı elde edebilmeleri için önemli etmenlerden birkaçı; çalışanlarına iş ortamlarında destek vermeleri, onlara yetki devretmeleri ve onların rahat ve huzurlu çalışabilecekleri bir ortam sağlamalarıdır. Örgütsel yaratıcılığın gerçekleşebilmesi ve sürekliliğinin sağlanması için çağdaş bir yönetim anlayışı olan Personel Güçlendirme kavramına önem verilmesi gerekmektedir bu sayede emek yoğun bir hizmet sektörü olan turizmde, insan unsurundan sağlanan fayda artırılabilir.

Çalışma Balıkesir ili, Gönen ilçesinde Gönen Kaplıcaları bünyesinde Kültür ve Turizm Bakanlığı İşletme Belgeli (4 yıldızlı) 1 otel ve hemen yanında Belediye tarifeli 4 konaklama tesisi istihdam edilen 151 çalışana anket yöntemi kullanılarak gerçekleştirilmiştir. Çalışmada bağımlı değişken Örgütsel Yaratıcılık, bağımsız değişken ise Spreitzer tarafından 1995'de geliştirilen personel güçlendirmeyi, 4 boyutta (Anlam, Yeterlilik, Özerklik ve Etki) 12 adet Likert tipi (5'li) ifade ile değerlendirmektedir. Araştırmada demografik özeliklere yönelik sorulara ilişkin frekans analizleri yapılmıştır. Araştırmada kullanılan değişkenlerin normal bir dağılım sergileyip sergilemediklerini test etmek amacıyla çarpıklık ve basıklık ölçebilmek için Skewness-Kurtosis (+1.5 ile -1.5$)$ testleri yapılmıştır daha sonra da ölçeklerin alt boyutlar bazındaki içsel tutarlılıklarını test etmek amacıyla Cronbach's Alpha içsel tutarlılık testleri yapılmıştır. Değişkenler arasındaki ilişkinin varlığını tespit edebilmek amacıyla 
Pearson korelasyon analizi yapılmış, son olarak da araştırmadaki nedensellik ilişkilerini test etmek için çoklu doğrusal regresyon analizleri yapılmış ve sonuçlara ilişkin istatistiki yorumlamalarda bulunulmuştur.

Regresyon analizine göre; Anlam, Özerklik ve Etki alt boyutların etkisi anlamlı, Yeterlilik boyutununki ise anlamsızdır. Buna göre Anlam alt boyutunda meydana gelen 1 birimlik artış, yaratıcılığ 0,346 birim arttırmaktadır. Aynı şekilde özerklik alt boyutunda meydana gelen 1 birimlik artış, yaratıcığı 0,334 birim arttırmaktadır. Etki alt boyutunda meydana gelen 1 birimlik artış yaratıcığı 0,322 birim arttırmaktadır. Yaratıcılığın varyansındaki değişimin \%45,5 lik bir kısmı, modele dahil olan değişkenler tarafından açıklanmaktadır. Araştırma sonucunda Personel Güçlendirmenin alt boyutları ile Örgütsel Yaratıcılık üzerine etkileri ile ilgili elde edilen sonuçların bu konuda daha önceki yapılan araştırmalarla benzerlik gösterdiği görülmektedir.

Çavuş 2006, yılında imalat sanayisine yönelik yaptığ çalışmada, 280 çalışana anket uygulamış ve personel güçlendirmenin alt boyutlarından anlam, yetkinlik ve yeteneğin örgütsel yaratıcılığı pozitif yönde etkilediği saptamışlardır. Ghorbani ve Ahmadi, 2011, yılında eğitim kurumlarında yaratıcılığın geliştirilmesi ve personel güçlendirmenin boyutları arasındaki ilişkiyi ele aldığı araştırmalarında, anlam, yetkinlik, özerklik ve etki boyutlarının tamamımın personel güçlendirme ile pozitif yönde ilişkiye sahip olduğunu tespit etmiştir. Araştırmacılar eğitim kurumlarında yönetici olarak görev yapan kişilerin, çalışanların yaratıcılığını olumsuz etkileyen unsurları ortadan kaldırması gerektiğini vurgulamıştır. Sun, v.d. (2012), Çin Halk Cumhuriyeti'nin Guangdong eyaletinde bulunan birden fazla ilaç firmasında; 385 çalışan ve onların 104 amirleriyle yaptıkları çalışmada iş ortamlarında güçlendirme uygulamalarının ve özerk bir çalışma ortamını geliştirmelerinin astların yaratıcılıklarını arttırdığını belirmişlerdir. Uzunbacak (2015), Isparta ve Burdur Organize Sanayi Bölgeleri'ndeki çalışanların katılımıyla yürüttüğü araştırmada, personel güçlendirmenin yaratıcılık üzerine etkisini incelemiştir. Araştırma bulguları güçlendirme ile ilgili tüm unsurlardaki desteklemelerin yaratıcılık üzerine pozitif yönde etki edebileceğini ortaya koymuştur. Kılınç (2018), Konya ilinde süt endüstrisinde faaliyet gösteren işletmelerde çalışan, 370 kişi ile yaptığı çalışmada personel güçlendirmenin alt boyutları olan anlam, yetkinlik, özerklik ve etki boyutlarının örgütsel yaratıcılık üzerinde pozitif yönlü ve anlamlı bir etkiye sahip olduğu tespit edilmiştir. Haykır (2018), Antalya'da faaliyet gösteren beş yıldızlı otel işletmelerinin mutfak bölümünde çalışan aşçılara yönelik bir araştırma gerçekleştirilmiştir. 502 mutfak personelinden elde edilen sonuçlara göre insan kaynakları 
yönetimi yaklaşımlarından olan personel güçlendirme ile yaratıcılık arasında pozitif anlamda bir ilişki bulunduğunu tespit edilmiştir.

Literatürde; personel güçlendirmenin, örgütsel yaratıcılık üzerine etkilerini araştıran pek çok araştırma olmasına rağmen, turizm sektöründe özellikle termal otel işletmelerinde bu konuları araştıran çalışmalar çok fazla değildir. Çalışmanın literatüre bu yönde katkı sağlayacağı düşünülmektedir. Araştırmanın uygulanması Balıkesir ili Gönen İlçesindeki termal otel işletmeleri ile sınırlı kalmıştır. Bu nedenle çalışmada geniş boyutlu genellemeler yapılamamaktadir.

Elde edilen sonuçlara göre; personel güçlendirme ile yaratıcılık arasında pozitif anlamda bir ilişki bulunmaktadır. Araştırma sonuçlarına göre, örgüt tarafından güçlendirilen çalışanların işletmesinde daha yaratıcı olmaya yatkın oldukları söylenebilir. Turizm sektörü, insan kaynağı devir hızının en hızlı yaşandığı ve kalifiye personel sıkıntısının yoğun olduğu alanlardan biridir.

Yoğun rekabet içerisinde, hizmet üretmeye çalışırken aynı zamanda müşteri memnuniyetini arttırmaya çalışan bu işletmeler arasındaki belirleyici fark; çalıştırdığı personel olabilmektedir. Bu aşamada, insan kaynakları yönetim teknikleri açısından personel güçlendirme ön plana çıkmaktadır. Konaklama işletmeleri, personeline yaptığı güçlendirme faaliyetleri sonrasında onların yaratıcılıklarının gelişmesine katkı sağladıklarında müşteri memnuniyetini arttırırken aynı zamanda rekabet avantajı sağlayacaklardır. 


\section{KAYNAKÇA}

Akgündüz, Y. 2013. 'Çalışanların Yaratıcılığına Motivasyon Araçlarının Etkisi: Kuşadası'ndaki Beş Yıldızlı Otel İşletmelerinde Bir Araştırma' Uluslararası Yönetim İktisat ve İşletme Dergisi 9 (20), 131-148.

Bolat, T. 2003. "Personeli Güçlendirme: Davranışsal ve Bilişsel Boyutta İncelenmesi ve Yönetim Kavramlarıyla Karşılaştırılması”, Atatürk Üniversitesi İ.I.B.F. Dergisi, 17(3-4), 199-219.

Brymer, R. A. 1991. "Employee Empowerment: A Guest-Driven Leadership Strategy”, wwww.ssrn.com.

Ceylan, A., Çöl, G. ve Gül, H. 2005. "İşin Anlamlılığının Belirleyen Sosyal-Yapısal Özelliklerin Güçlendirmeye Olan Etkileri ve Sonuçları Üzerine Bir Araştırma", Doğuş Üniversitesi Dergisi, 6(1): 35-51.

Choi, Ik-Sung, Chang, Young-Chul 2014. "Mediating effects of intrinsic motivation on the relationship between positive psychological capital, psychological empowerment and creativity", Journal of the Korea AcademiaIndustrial Cooperation Society, 15 (6), 3571-3586.

Conger, J.A., Kanungo, R.N. 1988. "The Empowerment Process: Integrating Theory and Practice”, Academy of Management Review, July, s.471-482.

Çavuş, F. M. 2006. "İşletmelerde Personel Güçlendirme Uygulamalarının Örgütsel Yaratıcılık ve Yeniliğe Etkileri Üzerine İmalat Sanayinde Bir Uygulama”. Doktora Tezi. Selçuk Üniversitesi Sosyal Bilimler Enstitüsü, Konya

Çavuş, F. M., Demir, Y. 2011. "Personel Güçlendirme ve Tükenmişlik: Sağlık Çalışanları Üzerine Bir Araştırma". III. Sağlıkta Performans ve Kalite Kongresi, Haziran, 216-222.

Durmuş, B., Yurtkoru, E. S. ve Çinko, M. 2013. Sosyal Bilimlerde SPSS'le Veri Analizi (6. Baskı). İstanbul: Beta Basim.

Eren, E. ve Gündüz H. 2002. "İş Çevresinin Yaratıcılık Üzerindeki Etkileri ve Bir Araştırma". Doğuş Üniversitesi Dergisi, 5: 65-84.

Ergeneli, A., Arı Sağlam, G. ve Metin, S. 2007. 'Psychological Empowerment and its Relationship to Trust in Immediate Managers'. Journal of Business Research, 60 (1), 41-56.

Frogoso, H. 2000.“An Overview of Employee Empowerment: Do's And Don'ts”, http://www.iusb.edu/ journal/2000/fragoso.html

Gürbüz, S. Şahin, F. 2014. Sosyal Bilimlerde Araştırma Yöntemleri. Ankara: Seçkin Yayınevi.

Ghorbani, M., Shahnaz A. 2011. "Relationship Between Employee's Empowerment Dimensions and Creativity İmprovement in Educational Organizations". Middle-East Journal of Scientific Research, 10 (2), 213217.

Haykır M. 2018. "Mutfak Çalışanlarında Personel Güçlendirme İle Yaratıcılık Süreci Arasındaki İlişkinin İncelenmesi”, Akdeniz Üniversitesi Sosyal Bilimler Enstitüsü, Turizm İşletmeciliği Ana Bilim Dalı, Yüksek Lisans Tezi.

Hu, Stella L. Y. and Leung, Louis 2003. "Effects of Expectancy-Value, Attitudes, and Use of The İnternet on Psychological Empowerment Experienced by Chinese Women at the Workplace", Telematics and Informatics, 20(4), 365-382.

Kabak, A. 2014. "İşletmelerde Personel Güçlendirme ve Denizli'de Bir Araştırma". Pamukkale Üniversitesi, Yüksek Lisans Tezi, Denizli.

Kendir, H., Özkoç A.G. 2019. "Konaklama İşletmelerinde Çalışan İşgörenlerin Örgütsel Yaratıcılık Algıları: Afyonkarahisar İli Örneği". Sosyal Bilimler Araştırmaları Dergisi 14: 149-167

Kılınç, S. 2018. "Psikolojik Sermaye Ve İşgören Güçlendirmenin Örgütsel Yaratıcılık Üzerindeki Etkisi”, Selçuk Üniversitesi Sosyal Bilimler Enstitüsü Doktora Tezi, Konya

Koçel, T. 2014. İşletme Yöneticiliği. İstanbul: Beta Basım Yayım Dağıtım A.Ş.

Kraimer, M. L., Seibert, S.E. ve Liden, R.C. 1999. 'Psychological Empowerment as a Multidimensional Construct: A Construct Validity Test'. Educational and Psychological Measurement, 59(1), 127-142.

Oldham, G., Cummings, A. 1996. "Employee Creativity: Personal and Contextual Factors at Work", The Academy of Management Journal, 39(3), 607-634

Önal, G. .1979. İşletmelerde Biçimsel Olmayan Örgüt Yapısı, Kalite Matbaası, Bursa

Örücü, E., Akgül V. ve Şeker C. 2019. "Personel Güçlendirme ve Güç Mesafesinin, İş Yerinde Yalnızlık Duygusu ile İşten Ayrılma Niyeti Üzerindeki Etkisi: Gönen Termal Örneği”, Türk Turizm Araştırmaları Dergisi, 3(4), ss.882-901.

Özdemir, S. 2017. Profesyonel Futbol Liginde Görev Alan Teknik Direktör Yardımcılarının Yaptıkları İşteki Güçlendirme Algılarının İncelenmesi, Marmara Üniversitesi, Sağlık Bilimleri Enstitüsü, Yüksek Lisans Tezi.

Pelit, E., Öztürk, Y., ve Arslantürk, Y. 2011. "The Effects of Employee Empowerment on Employee Job Satisfaction: A study on Hotels in Turkey". International Journal of Contemporary Hospitality Management, 23(6), 784- 802.

Rice, Gillian 2006. "Individual values, Organizational Context, and Selfperceptions of Employee Creativity: Evidence from Egyptian Organizations”, Journal of Business Research, 59(2), 233-241.

Samen, S. 2008. “İşletmelerde yaratıcılığın önemi” Ç.Ü., 17(2), 363-378. 
Sekaran, U. 2003. Research Methods for Business: A Skill Building Approach. 4th Edition, New York: John Wiley \& Sons Inc.

Sezgin, M , Zerenler, M , ve Karaman, A . 2008. "Otel İşletmelerinin Menü Planlamasında Yaratıcılık, Yenilikçilik, Girişimcilik Faaliyetleri Üzerine Bir Araştırma”. Sosyoekonomi , 8 (8)

Spreitzer, G. M. 1995. "Psychological Empowerment in the Workplace: Dimensions, Measurument, and Validation". Academy of Management Journal, 38 (5): 1442-1465.

Spreitzer, G. M. 1996. "Social Structural Characteristics of Psychological Empowerment". Academy of Management Journal, 39(2): 483-504.

Simonton, D. K. 2000. Creative Development as Acquired Expertise: Theoretical Issues and an Empirical Test, Developmental Review, 20(2), 283-318.

Sun, L. Y., Zhang, Z., Qi, J., \& Chen, Z. X. 2012. "Empowerment and Creativity: A Cross-level Investigation", The Leadership Quarterly, 23(1), 55-65.

Tabachnick, B. G., Fidell, L. S. 2007, Using Multivariate Statistics. Allyn \& Bacon/Pearson Education.

Tetik, N. 2015. "Turist Rehberlerinin Davranışsal Personel Güçlendirme Algıları". Işsletme Araştırmaları Dergisi, 7(3): 407-431.

Thomas, K.W., Velthouse, B.A. 1990. "Cognitive Elements of Empowerment: An "Interpretive" Model of Intrinsic Task Motivation”, Academy of Management Review, 15 (4), 666-681.

Toktamışoğlu, M. 2002. Kot Pantolonlu Yönetici. İstanbul: MediCat Kitapları.

Tsai, C.-Y., Horng, J.-S., Liu, C.-H., \& Hu, D.-C. 2015. "Work Environment and Atmosphere: The Role of Organizational Support in the Creativity Performance of Tourism and Hospitality Organizations". International Journal of Hospitality Management, 26-35.

Uğurlu, T. C., Ceylan, N. 2014. "Öğretmenlerin Örgütsel Yaratıcılık ve Etik Liderlik Algılarının İncelenmesi". Mersin Üniversitesi Ĕ̈itim Fakültesi Dergisi, 10(2): 96-112.

Uzunbacak, H. H. 2015. "The İmpacts of Employee Empowerment on İnnovation: A Survey on Isparta and Burdur Organized İndustrial Zones", The Journal of International Social Research, 8 (37), 977-989.

Watt, A. H. 2007. The Impact of Managerial Virtuality on Employee Performance. (Yayımlanmamış Doktora Tezi), Rensselaer Polytechnic Institute, Amerika.

Yazıcıŏglu, Y. ve Erdoğan, S. 2004. SPSS Uygulamalı Bilimsel Araştırma Yöntemleri. Ankara: Detay Yayıncılık 